\title{
Preparation, Characterization of NIPAM and NIPAM/BAM Copolymer Nanoparticles and their Acute Toxicity Testing Using an Aquatic Test Battery
}

\author{
Pratap Naha \\ Technological University Dublin, pratap.naha@tudublin.ie \\ Alan Casey \\ Technological University Dublin, alan.casey@tudublin.ie \\ Tiziana Tenuta \\ University College Dublin
}

See next page for additional authors

Follow this and additional works at: https://arrow.tudublin.ie/nanolart

Part of the Nanoscience and Nanotechnology Commons

\section{Recommended Citation}

Naha, P. et al (2009) Preparation, Characterization of NIPAM and NIPAM/BAM copolymer nanoparticles and their acute toxicity testing using an aquatic test battery. Aquatic Toxicology, 92, 146-154.

doi:10.1016/j.aquatox.2009.02.001

This Article is brought to you for free and open access by the NanoLab at ARROW@TU Dublin. It has been accepted for inclusion in Articles by an authorized administrator of ARROW@TU Dublin. For more information, please contact arrow.admin@tudublin.ie, aisling.coyne@tudublin.ie,gerard.connolly@tudublin.ie. Funder: INSPIRE programme, funded by the Irish Government's Programme for Research in Third Level Institutions, Cycle 4, National Development Plan 2007-2013. Additional funding from EPA (TT, 2006- PhDRCA-19) and EU FP6 STREP project Nanolnteract (IL)

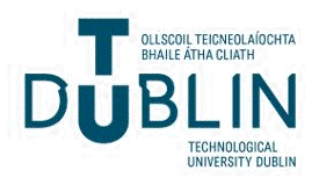




\section{Authors}

Pratap Naha, Alan Casey, Tiziana Tenuta, Iseult Lynch, Kenneth Dawson, Hugh Byrne, and Maria Davoren 
Elsevier Editorial System(tm) for Aquatic Toxicology

Manuscript Draft

Manuscript Number:

Title: Preparation, Characterization and Ecotoxicological evaluation of $\mathrm{N}$-isopropylacrylamide and $\mathrm{N}$-isopropylacrylamide-co- $\mathrm{N}$-tert-butylacrylamide Copolymer Nanoparticles.

Article Type: Original Research Paper

Section/Category:

Keywords: N-isopropylacrylamide (NIPAM); N-tert-butylacrylamide (BAM); Ecotoxicity; Nanoparticles; Zeta potential; structure-activity relationships.

Corresponding Author: Dr. Maria Davoren,

Corresponding Author's Institution:

First Author: Pratap C Naha

Order of Authors: Pratap C Naha; Alan Casey; Tiziana Tenuta; Iseult Lynch; Kenneth A Dawson; Hugh J Byrne; Maria Davoren

Manuscript Region of Origin:

Abstract: Poly N-isopropylacrylamide and N-isopropylacrylamide / N-tert-butylacrylamide copolymer nanoparticles of 50 to $70 \mathrm{~nm}$ were prepared by free radical polymerisation. The particle sizes of the copolymer nanoparticles were measured in the test media MilliQ water, Algae Media, Daphnia Media and Microtox Diluent as a function of temperature. Whereas in MilliQ water the particle size was seen to decrease above the lower critical solution temperature of the thermoresponsive polymer, in the test media it was seen to increase significantly, indicative of aggregation. At the temperatures employed for the ecotoxicological studies all particles, with the exception of the 50:50 copolymer existed as nanoparticles, however. The zeta potential of Poly $\mathrm{N}$-isopropylacrylamide and 
$\mathrm{N}$-isopropylacrylamide / $\mathrm{N}$-tert-butylacrylamide copolymer particles measured in the different media was seen to correlate well with the ratio of $\mathrm{N}$-tert-butylacrylamide monomer and therefore the hydrophobicity of the particles. Ecotoxicological studies of the copolymer nanoparticles was performed using four test species Vibrio fischeri, Pseudokirchneriella subcapitata, Daphnia magna, Thamnocephalus platyurus and the cytotoxicity of the $100 \%$ Poly $\mathrm{N}$-isopropylacrylamide and $85: 15$ $\mathrm{N}$-isopropylacrylamide / $\mathrm{N}$-tert-butylacrylamide copolymer nanoparticles was evaluated using a salmonid cell line. Although no significant cytotoxicological response was recorded, significant ecotoxicological response was observed at particle concentrations of up to $1000 \mathrm{mg} \mathrm{l}-1$. The ecotoxicological response was seen to correlate well with the ratio of $\mathrm{N}$-tert-butylacrylamide monomer and therefore with the zeta potential of the nanoparticles. The toxic response in Daphnia Magna was seen to further correlate with the reduction in zeta potential pointing towards a contribution of secondary effects due to modification of the medium. No correlation with particle size was observed. The sensitivity of the test species was seen to vary depending on co-polymer composition. The relevance of the derived structure activity relationships is discussed. 
Preparation, Characterization and Ecotoxicological evaluation of $\mathrm{N}$ isopropylacrylamide and $N$-isopropylacrylamide-co- $N$-tert-butylacrylamide Copolymer Nanoparticles.

Pratap C. Naha ${ }^{a}$, Alan Casey ${ }^{b}$, Tiziana Tenuta ${ }^{c}$, Iseult Lynch ${ }^{c}$, Kenneth A. Dawson $^{c}$, Hugh J. Byrne ${ }^{\mathrm{b}}$, Maria Davoren ${ }^{\mathrm{a} *}$

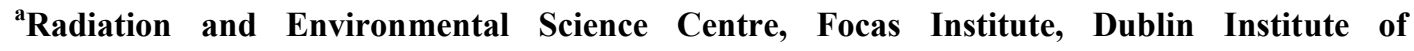
Technology, Kevin Street, Dublin 8, Ireland.

${ }^{b}$ Nanolab, Focas Institute, Dublin Institute of Technology, Kevin Street, Dublin 8, Ireland.

${ }^{\mathrm{c}}$ Centre for BioNano interactions, School of Chemistry and Chemical Biology and Conway Institute, University College Dublin, Belfield, Dublin 4, Ireland.

\section{* Corresponding Author}

Maria Davoren

Radiation and Environmental Science Centre, Focas Institute,

Dublin Institute of Technology

Kevin Street, Dublin 8. Ireland.

E-mail address: maria.davoren@dit.ie

$\mathrm{Ph}:+35314027974$

Fax: +35314027904 


\section{Abstract}

Poly $N$-isopropylacrylamide and $N$-isopropylacrylamide / $N$-tert-butylacrylamide copolymer nanoparticles of 50 to $70 \mathrm{~nm}$ were prepared by free radical polymerisation. The particle sizes of the copolymer nanoparticles were measured in the test media Milli-Q water, Algae Media, Daphnia Media and Microtox Diluent as a function of temperature. Whereas in Milli-Q water the particle size was seen to decrease above the lower critical solution temperature of the thermoresponsive polymer, in the test media it was seen to increase significantly, indicative of aggregation. At the temperatures employed for the ecotoxicological studies all particles, with the exception of the 50:50 copolymer existed as nanoparticles, however. The zeta potential of Poly $N$-isopropylacrylamide and $N$ isopropylacrylamide / $N$-tert-butylacrylamide copolymer particles measured in the different media was seen to correlate well with the ratio of $N$-tert-butylacrylamide monomer and therefore the hydrophobicity of the particles. Ecotoxicological studies of the copolymer nanoparticles was performed using four test species Vibrio fischeri, Pseudokirchneriella subcapitata, Daphnia magna, Thamnocephalus platyurus and the cytotoxicity of the $100 \%$ Poly $N$ isopropylacrylamide and 85:15 N-isopropylacrylamide / N-tert-butylacrylamide copolymer nanoparticles was evaluated using a salmonid cell line. Although no significant cytotoxicological response was recorded, significant ecotoxicological response was observed at particle concentrations of up to $1000 \mathrm{mg}^{-1}$. The ecotoxicological response was seen to correlate well with the ratio of $N$-tertbutylacrylamide monomer and therefore with the zeta potential of the nanoparticles. The toxic response in Daphnia Magna was seen to further correlate with the reduction in zeta potential pointing towards a contribution of secondary 
effects due to modification of the medium. No correlation with particle size was observed. The sensitivity of the test species was seen to vary depending on copolymer composition. The relevance of the derived structure activity relationships is discussed.

Keywords $N$-isopropylacrylamide (NIPAM); N-tert-butylacrylamide (BAM); Ecotoxicity; Nanoparticles; Zeta potential; structure-activity relationships. 


\section{Introduction}

Polymeric nanoparticles are widely used in different aspects of the medical field in terms of diagnosis, tissue engineering and as drug delivery devices (Storrie and Mooney, 2006). Several polymeric micro- and nanoparticles have been used for the delivery of drugs and therapeutic proteins (Silva et al., 2006; Blasi et al., 2007). In particular polylactic-co-glycolic acid (PLGA) and poly-lactic acid (PLA) polymers, which are biodegradable in nature, show great potential and have been widely used in drug delivery systems (Ito et al., 2008; Naha et al., 2008a,b; Sun et al., 2008). Currently four other nanoparticles namely, polymer coated iron oxide nanoparticles, PEGylated liposomes, dendritic fullerenes, and fullerene derivative nanoparticles are being investigated in clinical trials for their anticancer activity (Dobrovolskaia and McNeil, 2007).

Several types of polymeric nanoparticles have also been developed and proposed for soil and ground water remediation. Micelle-like amphiphilic polyurethane particles have a hydrophilic outer side and hydrophobic inner core and are therefore very well suited for removal of hydrophobic pollutants from soils (Kim et al., 2000, 2003a,b). Polymeric dendrimers have also been developed for removal of heavy metals from soil by acting as water soluble chelators (Xu and Zhao, 2005, 2006).

Poly $N$-isopropylacrylamide (PNIPAM) is a well known thermoresponsive polymer (Hsiue et al., 2002). It exhibits a lower critical solution temperature (LCST) of about $32^{\circ} \mathrm{C}$ in an aqueous medium (Xu et al., 2006). Copolymerisation of NIPAM with the more hydrophobic monomer $N$-tert-butylacrylamide (BAM) reduces the PNIPAM LCST with increasing percentage of the BAM monomer. As the ratio of BAM increases, the amount of $\mathrm{N}-\mathrm{H}$ groups exposed at the surface 
decreases, and the amount of $-\mathrm{C}-\left(\mathrm{CH}_{3}\right)_{3}$ groups increases, reducing the hydrophillicity of the resulting copolymer. For example LCSTs for the polymers with monomer ratios NIPAM/BAM 85:15, NIPAM/BAM 65:35, NIPAM/BAM 50:50 are $25^{\circ} \mathrm{C}, 17^{\circ} \mathrm{C}$ and $12^{\circ} \mathrm{C}$ respectively (Lynch et al., 2005). Because of this reversible phase transition, PNIPAM has been widely used in the preparation of stimuli responsive systems for biomedical applications, such as in the controlled release of drugs and in tissue engineering (Xu et al., 2004; Zhang et al., 2005; Kavanagh, 2005; Xu et al., 2006). PNIPAM has also been developed and proposed for controlled release of opthalmic drops for glaucoma therapy (Hsiue et al., 2002, 2003). Recently the effect of NIPAM/BAM copolymer nanoparticles of varying size and varying copolymer ratios on adsorption of proteins from plasma and the potential implications for biological interactions has been reported (Cedervall et al., 2007).

As nanomaterials are currently being widely used in modern technology, there is an increasing need for information regarding the human health and environmental implications of these nanomaterials. To date the human health impacts of nanomaterials have received the greatest attention and it has been demonstrated through both in vivo and in vitro studies with mammalian test systems that the properties that make nanomaterials so attractive from a commercial application viewpoint (e.g. nanoparticle size and increased surface area) can also potentially be responsible for undesirable health effects (Oberdörster et al., 2005, Meng et al., 2007; Papageorgiou et al., 2007; Singh et al., 2007; Poland et al., 2008). Recently, several nanoparticles, including the NIPAM/BAM copolymer nanoparticles used here, were found to enhance the rate of protein fibrillation of $\beta$-2-microglobulin, which is implicated in dialysis related 
amyloidogenesis, in solution experiments at $\mathrm{pH} 2$ by a surface catalysis type mechanism (Linse et al., 2007). More recently, the NIPAM/BAM copolymer particles have been shown to retard or even reverse the fibrillation of amyloid- $\beta$, the protein involved in Alzheimer's disease (Cabaleiro-Lago et al., 2008), also in solution experiments, indicating that such processes are complex and depend on the nature of both the particle and the protein. However, to our knowledge there have been no reports on the environmental impact of these copolymer particles.

The assessment of environmental effects requires an understanding of their mobility, reactivity, ecotoxicity and persistency (Nowack and Buchelli, 2007). Recently reports on the ecotoxicity of various nanomaterials have started to emerge in the literature. Of the studies conducted, the majority have focused on the carbon based materials (Lovern and Klaper, 2006; Zhu et al., 2006; Cheng et al., 2007; Lin and Xing, 2007; Smith et al., 2007; Baun et al., 2008; Lovern et al., 2007) but there have also been recent reports on the ecotoxicological evaluation of various metal based nanomaterials (Lovern et al., 2007; Federici et al., 2007; Heinlaan et al., 2008; Gagńe et al., 2008; Mortimer et al., 2008) and dendrimers (Mortimer et al., 2008). These studies have looked at various aquatic species representing the different trophic levels (decomposer, primary producer, invertebrates and vertebrates).

The aim of the present investigation was therefore the preparation, characterisation and ecotoxicological assessment of PNIPAM and NIPAM/BAM copolymer nanoparticles. Variation of the co-polymerisation ratio from $100 \%$ NIPAM through NIPAM/BAM 85:15, NIPAM/BAM 65:35 and NIPAM/AM 50:50 allowed a systematic variation of the surface chemistry which manifested as changes in the Zeta potential, facilitating the establishment of structure-activity relationships. 
Since these particles are thermosensitive, the particle size was measured as a function of temperature. The surface area of the particles was measured by BET. Investigation of the acute ecotoxicological effects of PNIPAM and NIPAM/BAM copolymer particles was conducted using a battery of bioassays representing different trophic levels. The tests employed included a bacterial species, a unicellular algae species and two crustaceans. In addition, the cytotoxicity of PNIPAM and NIPAM/BAM (85:15) copolymer particles was investigated in a salmonid fish cell line.

\section{Materials and methods}

\subsection{Test compounds}

Poly N-isopropylacrylamide (PNIPAM) and N-isopropylacrylamide-co- $N$-tertbutylacrylamide (NIPAM/BAM) copolymer particles with three different ratios of the comonomers $(85: 15,65: 35$, and 50:50 NIPAM/BAM) were synthesised by free radical polymerisation. The procedure for the synthesis was as follows: $2.8 \mathrm{~g}$ monomers (in the appropriate $\mathrm{wt} / \mathrm{wt}$ ratio), and $0.28 \mathrm{~g}$ crosslinker (N,Nmethylenebisacrylamide) was dissolved in $190 \mathrm{ml}$ MilliQ water [MQ] with $0.8 \mathrm{~g}$ SDS and degassed by bubbling with nitrogen gas for 30 minutes. Polymerisation was induced by adding $0.095 \mathrm{~g}$ ammonium persulfate initiator in $10 \mathrm{ml}$ MQ water and heating at $70^{\circ} \mathrm{C}$ for 4 hours. Particles were extensively dialysed against MQ water for several weeks, changing the water daily, until no traces of monomers, crosslinker, initiator or SDS could be detected by proton NMR (spectra acquired in $\mathrm{D}_{2} \mathrm{O}$ using a $500 \mathrm{MHz}$ Varian Inova spectrometer). Particles were freeze-dried and stored in the 
fridge until used. Transmission Electron measurements confirmed the as produced particles to be of size $30-50 \mathrm{~nm}$ in the dry state (personal communication).

Due to the inverse solubility of PNIPAM and NIPAM/BAM particles, solutions were prepared by dispersing the particles on ice to ensure good solubility of the particles (i.e. to ensure that the solutions are below the lower critical solution temperature of the particles and thus that polymer-water contacts are more favourable than polymer-polymer contacts resulting in uptake of water and swelling of the particles), before gradually warming them to the test conditions.

Phenol (CAS No. 108-95-2) and potassium dichromate (CAS No. 7778-50-9) were purchased from Sigma-Aldrich (Ireland) and employed as reference toxicants (positive controls) to validate the test procedures.

\subsection{Particle Characterisation}

\subsubsection{Particle size measurement}

The particle size distributions of all particles in the appropriate assay media were analyzed using a Zeta sizer (Malvern Instruments, UK). For a typical experiment approximately $1.5 \mathrm{ml}$ of a $1000 \mu \mathrm{g} / \mathrm{ml}$ concentration suspension of nanoparticles in MQ water and the respective assay media (i.e. algal medium [AM], Daphnia medium [DM] and Microtox ${ }^{\circledR}$ diluent $[\mathrm{MD}]$ ) were analysed as a function of temperature from $0^{\circ} \mathrm{C}$ to $30^{\circ} \mathrm{C}$ with an interval of $5^{\circ} \mathrm{C}$. 


\subsubsection{Zeta potential measurement}

The Zeta potential of all particles in MQ water and the respective assay media was measured using the Zeta sizer (Malvern Instruments, UK). Although the zeta potential are also affected by temperature (size), measurements were conducted at $20{ }^{\circ} \mathrm{C}$ only, using a concentration of $1000 \mu \mathrm{g} / \mathrm{ml}$.

\subsubsection{Surface Area measurement}

BET surface area measurements were performed using a Gemini series surface area analyser (Micromeritics, USA). Approximately $0.5 \mathrm{~g}$ particles of each of the materials were degassed with nitrogen gas at a constant temperature of $25{ }^{\circ} \mathrm{C}$ for two hours prior to surface area measurements being recorded.

\subsection{Ecotoxicity tests}

Each ecotoxicity test was performed in two stages. A preliminary or range finding test was conducted which determined the range of concentrations of interest for the definitive test. The definitive test used a concentration range (at least five concentrations) in which effects were likely to occur thereby permitting the calculation of the respective Effective Concentrations $\left(\mathrm{EC}_{10}, \mathrm{EC}_{50}\right)$ or Lethal Concentrations $\left(\mathrm{LC}_{10}, \mathrm{LC}_{50}\right)$, No Observed Effect Concentration (NOEC), and Lowest Observed Effect Concentration (LOEC). The acute toxicity of PNIPAM and each of the NIPAM/BAM copolymer particles was investigated in four test systems representing different trophic levels. The cytotoxicity of PNIPAM and PNIPAM/BAM 85:15 was also evaluated in the RTG-2 salmonid fish cell line. 


\subsubsection{Microtox ${ }^{\circledR}$ test}

The acute toxicity of PNIPAM and each of the PNIPAM/BAM copolymers to the marine bacterium Vibrio fischeri was determined using the $90 \%$ basic test for aqueous extract protocol (Azur Environmental Ltd, 1998). Lyophilised Vibrio fischeri bacteria (NRRL B-11177) and all Microtox ${ }^{\circledR}$ reagents were obtained from SDI Europe, Hampshire, UK. Exposure was carried out at $15^{\circ} \mathrm{C}$ in Microtox ${ }^{\circledR}$ diluent. Phenol was used as a reference chemical and a basic test for phenol was run for every fresh vial of bacteria to ensure the validity of all tests. Readings of bioluminescent response were measured using a Microtox ${ }^{\circledR}$ Model 500 analyser and the acute toxicity data was obtained and analysed using the MicrotoxOmni software (SDI Europe, Hampshire, $\mathrm{UK})$. Five, fifteen and thirty minute $\mathrm{EC}_{50}$ tests were performed.

\subsubsection{Microalgae growth inhibition assay}

Assessment of the acute toxicity of the materials to the freshwater algae Pseudokirchneriella subcapitata was conducted in accordance with OECD Guideline 201 (2002). Pseudokirchneriella subcapitata CCAP 278/4 was obtained from the Culture Collection of Algae and Protozoa (CCAP) Argyll, Scotland. All microalgae growth inhibition tests were conducted at $20 \pm 1{ }^{\circ} \mathrm{C}$ with continuous shaking at 100 rpm and continuous illumination of 10,000 lx. The initial algal density of all flasks was $1 \times 10^{4}$ cell ml $\mathrm{m}^{-1}$ in a final volume of $20 \mathrm{ml}$. Negative controls were incorporated for each test containing only algal growth media and algal inoculum. The cell density of each replicate was measured after $72 \mathrm{~h}$ using a Neubauer Improved (Bright-Line) chamber (Brand, Germany). Average specific growth rate $(\mu)$ and percentage inhibition of average specific growth rate (\%Ir) relative to controls were calculated for 
each concentration. The reference chemical potassium dichromate was employed as a positive control to ensure validity of the test method.

\subsubsection{Thamnotoxkit $F^{T M}$}

The acute toxicity of the materials was also evaluated using the freshwater shrimp Thamnocephalus platyurus. This toxicity test was purchased in kit form from SDI Europe (Hampshire, UK) and the test was performed according to manufacturer's instructions (Thamnotoxkit $\mathrm{F}^{\mathrm{TM}}$, 1995). Briefly, the test is a $24 \mathrm{~h} \mathrm{LC}_{50}$ bioassay, which is performed in a 24-well test plate using instars II-III larvae of the shrimp, which are hatched from cysts. Hatching was initiated $24 \mathrm{~h}$ prior to the start of the test. Upon hatching, shrimp were exposed to various concentrations of PNIPAM and each NIPAM/BAM copolymer nanoparticle and incubated at $25{ }^{\circ} \mathrm{C}$ for $24 \mathrm{~h}$ in the dark. The test endpoint was mortality. The number of dead shrimp for each concentration was recorded and the respective $\mathrm{LC}_{50}$ was determined. Potassium dichromate was used as a positive control.

\subsubsection{Daphnia magna acute immobilisation assay.}

Acute toxicity immobilization tests were performed on each of the nanoparticles according to the British standard (BS EN ISO 6341, 1996). Daphnia magna were originally obtained from TNO laboratories (the Netherlands) and were cultured in static conditions at $20 \pm 1{ }^{\circ} \mathrm{C}$ and under $16 \mathrm{~h} / 8 \mathrm{~h}$ light/dark photoperiod. Daphnid sensitivity was verified by determining the $24 \mathrm{~h} \mathrm{EC}_{50}$ using potassium dichromate. Acute toxicity tests were performed on Daphnia magna neonates that were less than 
$24 \mathrm{~h}$ old. Four replicates were tested for each test concentration and five neonates were used in each replicate. There was no feeding during the tests. Immobilisation (no independent movement after gentle agitation of the test liquid for $15 \mathrm{~s}$ ) was determined visually after 24 and $48 \mathrm{~h}$.

\subsubsection{Cell culture}

RTG-2 cells (Catalogue no. 90102529), a rainbow trout gonadal cell line, were used for the cytotoxicity testing of PNIPAM and NIPAM/BAM 85:15 only. These cells were obtained from the European Collection of Cell Cultures (Salisbury, UK). Cells were maintained in Dulbecco's Modified Medium Nutrient Mixture/F-12 Ham (DMEM) supplemented with $10 \%$ foetal calf serum (FCS) and $45 \mathrm{IU} \mathrm{ml}^{-1}$ penicillin, $45 \mu \mathrm{g} \mathrm{ml}^{-1}$ streptomycin. The RTG-2 medium was also supplemented with $25 \mathrm{mM}$ HEPES and 1\% non-essential amino acids. Cultures were maintained in a refrigerated incubator at a temperature of $20^{\circ} \mathrm{C}$ under normoxic atmosphere.

2.3.5.1. Cytotoxicity assays. For cytotoxicity tests, stock flasks were trypsinised and cells plated with $100 \mu \mathrm{l}$ of the following cell suspension concentrations: 2 × $10^{5}$ cells per $\mathrm{ml}$ for $24 \mathrm{~h}$ exposure periods, $1.8 \times 10^{5}$ cells per $\mathrm{ml}$ for the $48 \mathrm{~h}$ exposures, and $1.6 \times 10^{5}$ cells per $\mathrm{ml}$ for the 72 and $96 \mathrm{~h}$ exposure periods (Davoren et al., 2005). These seeding densities were found to be optimal to achieve the desired confluency for each cell line at the end of each respective exposure period. Test particles were prepared in a reduced serum medium $(5 \% \mathrm{FCS})$ to lessen the effects of the particles binding serum proteins. Fish cells were exposed to the nanoparticles in a range of 
concentrations $\left(\mathrm{mg} \mathrm{l}^{-1}\right)$ based on the preliminary range finding tests with the cell line. Six replicate wells were used for each control and test concentration per microplate. After each incubation period $(24,48,72$, or 96 h), morphological damage was evaluated in comparison to the controls. The test medium was removed; cell monolayers washed with phosphate buffered saline (PBS) and prepared for the cytotoxicity assays. The Alamar Blue (AB) and Neutral Red (NR) assays were subsequently conducted on the same set of plates, as previously described (Davoren and Fogarty, 2006).

\subsection{Statistics}

All experiments were conducted in at least triplicate (three independent experiments). Toxicity was expressed as mean percentage inhibition for the Microtox ${ }^{\circledR}$ (bioluminescence), P. subcapitata (growth) and D. magna (immobilisation) and percentage mortality was measured for the T. platyurus assay. Fluorescence (AB and NR assays) as fluorescent units (FUs) was quantified using a microplate reader (TECAN GENios, Grödig, Austria). Raw data from cell cytotoxicity assays were collated and analyzed using Microsoft Excel $^{\circledR}$ (Microsoft Corporation, Redmond, WA). Cytotoxicity was expressed as mean percentage inhibition relative to the unexposed control \pm standard deviation (SD). Statistical analyses were carried out using one-way analyses of variance (ANOVA) followed by Dunnett's multiple comparison tests. Statistical significance was accepted at $P \leq 0.05$ for all tests. Toxicity data was fitted to a sigmoidal curve and a four parameter logistic model used to calculate $\mathrm{EC} / \mathrm{LC}_{50}$ values. This analysis was preformed using $\mathrm{Xlfit}^{\mathrm{TM}}$ a curve fitting add-in for Microsoft ${ }^{\circledR}$ Excel (ID Business Solutions, UK). 


\section{Results}

\subsection{Nanoparticle characterisation}

\subsubsection{Particle size measurement}

The average particle sizes of PNIPAM, and the various NIPAM/BAM copolymer nanoparticles were measured as a function of increasing temperature. PNIPAM and NIPAM/BAM copolymers are thermoresponsive in nature. When the temperature is raised above the LCST the polymer undergoes a phase transition and the random coil structure (hydrophilic state) collapses to form a globular structure (hydrophobic state) (Xu et al., 2006).

This behaviour of decreasing particle size with increasing temperature is demonstrated well by the temperature dependence of the nanoparticles when prepared in MQ water (data not shown). In our experiments the particle size of NIPAM and NIPAM/BAM copolymer nanoparticles were found to increase with increasing temperature when they were prepared in other media, however, as presented in Figure 1a for the example of the Microtox ${ }^{\circledR}$ diluent, MD. For the 50:50 copolymer, the particle size is seen to begin to increase significantly at $\sim 10^{\circ} \mathrm{C}$, close to its LCST. As shown in figure $1 \mathrm{~b}$, the particle size becomes as high as microns. This dramatic increase of particle size is characteristic of aggregation. As shown in Figure 1, the 63:35 and 85:15 copolymer particles remain unaggregated until $\sim 15^{\circ} \mathrm{C}$ and $20^{\circ} \mathrm{C}$ respectively and the $100 \%$ PNIPAM until $25^{\circ} \mathrm{C}$. Table 1 lists the average particle size of the various co-polymer particles in the respective test media, at the temperatures at which the respective tests were conducted. With the exception of the 50:50 copolymer, all particles are unaggregated at the concentrations and temperatures employed for the eco- toxicological studies. In cell culture medium, both the 50:50 
and $65: 35$ copolymer particles were seen to be highly aggregated at $20^{\circ} \mathrm{C}$, and so were not tested.

\subsubsection{Zeta potential measurement}

The zeta potentials of PNIPAM and the different NIPAM/BAM copolymer particles was measured in the various test media; MQ water, MD, AM, and DM. The results are shown in Figure 2. For all media types, increasing the ratio of BAM in the copolymer nanoparticles was shown to cause a decrease in their zeta potential. This increasingly negative value of the zeta potential of the co-polymer particle surface is consistent with the reduced hydrophillicity (as determined by contact angle measurements) as a result of the increased BAM content (Lynch et al., 2005; Allen et al., 2003). A similar trend was observed with all the media tested but was most significant when the nanoparticles were tested in MQ water. Such a decrease in the zeta potential of nanoparticles in growth media is commonly observed (Hang et al., 2007) and is attributable to shielding of the potential due to adsorption of components of the medium by the nanoparticles. No correlation between zeta potential and particle size was observed.

\subsubsection{Surface Area measurement}

The surface area of PNIPAM, NIPAM/BAM 85:15, NIPAM/BAM 65:35 and NIPAM/BAM 50:50 particles was found to be $5.77 \pm 0.07 \mathrm{~m}^{2} / \mathrm{g}, 9.57 \pm 0.06 \mathrm{~m}^{2} / \mathrm{g}$, $14.1 \pm 0.1 \mathrm{~m}^{2} / \mathrm{g}$ and $8.5 \pm 0.1 \mathrm{~m}^{2} / \mathrm{g}$ respectively. With the exception of the $50: 50$ copolymer, the surface areas correlate reasonably with the particle size. 


\subsection{Ecotoxicity}

Testing of reference chemicals in tandem with the polymer nanoparticles was carried out to ensure the validity of each test method. Endpoints of all reference toxicity tests were within those stipulated in each respective standard guideline or reported in previous studies (Nyholm, 1990; Thamnotoxkit $\mathrm{F}^{\mathrm{TM}}$, 1995; BS EN ISO 6341, 1996; Azur Environmental, 1998). Consistent results were achieved for each test control in accordance with the criteria for validity of each test guideline.

The dose dependent effects of the PNIPAM and NIPAM/BAM particles in the algal tests are shown in Figure 3. The effects of each of the materials on the invertebrate Daphnia magna and Thamnocephalus platyurus are presented in Figures 4 and 5 respectively. The cytotoxicity of P(NIPAM) and NIPAM/BAM 85:15 particles was tested in the concentration range $25-1000 \mathrm{mg} \mathrm{l}^{-1}$ in the $\mathrm{RTG}-2$ cell line at four time points up to $96 \mathrm{~h}$. No significant toxicity was found at any of the test concentrations with either of the endpoints studied at any of the time points (results not shown).

\subsubsection{Ecotoxicity test results with PNIPAM}

The results of the ecotoxicity assessment of PNIPAM particles with the four test systems are presented in Table 2. Employing the calculated ecotoxicity value $\left(\mathrm{EC}_{50} / \mathrm{LC}_{50}\right)$, in terms of species sensitivity the ranking order for PNIPAM particles is as follows Daphnia magna > Thamnocephalus platyurus $>$ Vibrio fischeri $>$ Pseudokirchneriella subcapitata. 


\subsubsection{Ecotoxicity test results with NIPAM/BAM 85:15}

The results of the ecotoxicity evaluation of NIPAM/BAM 85:15 with the test systems are presented in Table 3. Based on the calculated ecotoxicity value $\left(\mathrm{EC}_{50} / \mathrm{LC}_{50}\right)$, in terms of species sensitivity, the ranking order for NIPAM/BAM 85:15 nanoparticles is as follows Daphnia magna > Thamnocephalus platyurus > Vibrio fischeri > Pseudokirchneriella subcapitata, as was the case for the parent polymer PNIPAM.

\subsubsection{Ecotoxicity tests with NIPAM/BAM 65:35}

The results of the ecotoxicity assessment of NIPAM/BAM 65:35 particles with the different test systems are presented in Table 4. Employing the calculated ecotoxicity value $\left(\mathrm{EC}_{50} / \mathrm{LC}_{50}\right)$, in terms of species sensitivity the ranking order for NIPAM/BAM 65:35 particles is as follows Vibrio fischeri > Daphnia magna > Thamnocephalus platyurus $>$ Pseudokirchneriella subcapitata.

\subsubsection{Ecotoxicity tests with NIPAM/BAM 50:50}

The results for NIPAM/BAM 50:50 particles from the different test systems are presented in Table 5. Employing the calculated ecotoxicity value $\left(\mathrm{EC}_{50} / \mathrm{LC}_{50}\right)$ in terms of species sensitivity the ranking order for NIPAM/BAM 50:50 nanoparticles to the test species is as follows Vibrio fischeri $>$ Daphnia magna $>$ Thamnocephalus platyurus > Pseudokirchneriella subcapitata. 


\section{Discussion}

\subsection{Physico-chemical parameters:}

\subsubsection{Particle size}

The particle size of the different materials was measured in different media. As thermoresponsive polymers, the particles exhibit a random coil structure (hydrophilic state) below the LCST and collapsed globular structure (hydrophobic state) above the LCST (Zhang et al., 2001). As the BAM ratio increases, the LCST of the composite NIPAM/BAM particles decreases (Lynch et al., 2005). The particle size decreases as a result of the collapse as was found to be the case in MQ water (data not shown). The particle size of NIPAM and NIPAM/BAM copolymer nanoparticles was found to increase with increase in temperature in $\mathrm{AM}, \mathrm{DM}$, and MD media, however, as presented in Figure 1a and $\mathrm{b}$ (data not shown for AM and DM). As the materials under go the phase transition, the average particle size increases to several microns, characteristic of aggregation., as a consequence of the screening effect of the salts in the various test media. It is proposed therefore that the particles interact with different components of the media and aggregate when the temperature is increased above the respective LCST.

\subsubsection{Zeta potential}

The zeta potential of PNIPAM and the different NIPAM/BAM copolymer nanoparticles was shown to decrease (NIPAM < NIPAM/BAM 85:15 < NIPAM/BAM 65:35 NIPAM/BAM 50:50) with increasing BAM ratio as presented in Figure 2. The zeta potential thus correlates well with the reduction of the hydrophillicity of the particle surface. The zeta potential of PNIPAM and the different NIPAM/BAM copolymer particles was measured in the various media 
systems and it was demonstrated that this decrease in zeta potential as a function of particle composition was much more pronounced in MQ water compared to the other test media (AM, MD and DM). It is therefore proposed that the zeta potential is screened due to interaction with various components present in media. Notably, a clear correlation between zeta potential and NIPAM/BAM ratio is demonstrated in Figure 2 for all growth media.

\subsection{Ecotoxicology}

\subsubsection{PNIPAM}

Poly $N$-isopropylacrylamide particles were found to be the least toxic among all the NIPAM/BAM copolymer particles tested in this study. The most sensitive test species to PNIPAM nanoparticles was the Daphnia magna (48 hour $\mathrm{EC}_{50} 413.6 \mathrm{mg} \mathrm{l}^{-}$

${ }^{1}$ ) and the least sensitive test species was the Pseudokirchneriella subcapitata (72 hour $\mathrm{EC}_{50}>1000 \mathrm{mg} \mathrm{l}^{-1}$ ).

\subsubsection{NIPAM/BAM 85:15}

The NIPAM/BAM 85:15 nanoparticles demonstrated a very similar toxicity profile to PNIPAM with Daphnia magna being the most sensitive test species (48 hour $\mathrm{EC}_{50}$ is $449.6 \mathrm{mg} \mathrm{l}^{-1}$ ) and Pseudokirchneriella subcapitata the least sensitive (72 hour $\mathrm{EC}_{50}$ is $\left.>1000 \mathrm{mg} \mathrm{l}^{-1}\right)$. 


\subsubsection{NIPAM/BAM 65:35}

NIPAM/BAM 65:35 nanoparticles were shown to be more toxic than PNIPAM and, and this increase in toxicity was attributed to the increase in BAM ratio in the copolymer nanoparticles. There was a change in the test species sensitivity to this particle in comparison to PNIPAM and NIPAM/BAM 85:15 nanoparticles with the bacterium Vibrio fischeri (5 minutes $\mathrm{EC}_{50} 40.5 \mathrm{mg} \mathrm{1}^{-1}$ ) showing greater sensitivity than the Daphnia magna bioassay in this case. The least sensitive test species are Pseudokirchneriella subcapitata $\left(72\right.$ hour $\mathrm{EC}_{50} 727.1 \mathrm{mg} \mathrm{l}^{-1}$ ).

\subsubsection{NIPAM/BAM 50:50}

NIPAM/BAM 50:50 nanoparticles were found to be the most toxic to the test battery compared to the other three copolymer nanoparticles. The species sensitivity to these particles was found to be in the same order as that of the NIPAM/BAM 65:35 nanoparticles with Vibrio fischeri (5 minutes $\mathrm{EC}_{50} 25.7 \mathrm{mg} \mathrm{l}^{-1}$ ) as the most sensitive and Pseudokirchneriella subcapitata $\left(72\right.$ hour $\mathrm{EC}_{50} 706.7 \mathrm{mg}^{-1}$ ) as the least sensitive test.

\subsection{Summary}

Ecotoxicological assessment of NIPAM and NIPAM/BAM copolymer nanoparticles was carried out in different test species, namely bacteria (Vibrio fischeri), algae (Pseudokirchneriella subcapitata), invertebrates (Daphnia magna and Thamnocephalus platyurus) and a fish cell line RTG-2 which represented a vertebrate model in the test battery. The sensitivity of the test species varied as the 
physicochemical characteristics of the PNIPAM and NIPAM/BAM copolymer particles changed. The most sensitive bioassay for PNIPAM and NIPAM/BAM 85:15 particles was found to be the immobilisation of Daphnia magna (48 hour $\mathrm{EC}_{50}$ ) followed by mortality of Thamnocephalus platyurus ( 24 hour $\left.\mathrm{LC}_{50}\right)$. The most sensitive test for NIPAM/BAM 65:35 and NIPAM/BAM 50:50 particles was the Microtox ${ }^{\circledR}$ assay (Vibrio fischeri, 5 minutes $\mathrm{EC}_{50}$ ) followed by the immobilisation of Daphnia magna (48 hour $\mathrm{EC}_{50}$ ) and mortality of Thamnocephalus platyurus (24 hour $\mathrm{LC}_{50}$ ). The least sensitive bioassay was the Pseudokirchneriella subcapitata (72 hour $\mathrm{LC}_{50}$ ) for the four test particles. The cytotoxicity of PNIPAM and NIPAM/BAM 85:15 was studied in RTG-2 cells and from this study it was observed that there was no significant difference in terms of cell viability between control and cells exposed to the polymer particles. Neither the PNIPAM nor NIPAM/BAM 85:15 particles were found to be toxic to the fish cells at the concentrations and timepoints tested in this study. Cytotoxicity in RTG-2 was assessed at the recommended growth temperature of $20^{\circ} \mathrm{C}$. NIPAM/BAM 65:35 and NIPAM/BAM 50:50 were demonstrated to form large aggregates at this temperature, due to the low LCST, which led to both materials floating in the cell culture media. For a cytotoxicity assessment the particles should be fully dispersed and capable of interaction with the cells so in this case it was not considered practical to test these particles with the cell line.

The toxicity of the polymer nanoparticles gradually increased in all of the test species (except RTG-2 cells) as a function of increasing BAM ratio. This relationship with increasing ratio of $\mathrm{BAM}$ is shown for the $\mathrm{EC}_{50}$ of the 24 and $48 \mathrm{~h}$ acute immobilisation test with Daphnia magna in Figure 6. An increase in the ratio of the monomer BAM was also shown to cause a concomitant decrease in the $\mathrm{LC}_{50}$ value 
(i.e. more toxic) following $24 \mathrm{~h}$ exposure of the invertebrate Thamnocephalus platyurus (Figure 7). The monomer ratio has, however, also been shown to be correlated to the measured zeta potential and therefore the measured ecotoxic response can be correlated with the zeta potential as shown in Figure 8.

No correlation with particle size was observed for the test results and thus the increased toxic response must be associated with the decreased hydrophillicity and therefore zeta potential of the copolymer particles with increasing BAM content. For a given particle composition, the zeta potentials are significantly reduced in all growth media, indicating a further decrease of hydrophillicity due to charge screening by the ionic salts of the media. It is worth noting that, for the 50:50 and 65:35 NIPAM/BAM copolymer nanoparticles, the degree of screening is highest for the Microtox diluent (Figure 2), and that this assay shows the highest sensitivity for these particles. For the PNIPAM and 85:15 NIPAM/BAM particles, the most screened zeta potential is in the Daphnia medium, and again the Daphnia assay was seen to be the most sensitive assay for these particles. This observation may point towards a better understanding of the mechanisms of the toxic response. In, for example, studies of the toxic response of mammalian cells to carbon nanotubes, it has been seen that medium depletion by interaction with the molecular components of the medium results in a significant indirect toxic response (Casey et al., 2008). The interaction with the medium components implied here could similarly contribute to the toxic response observed. The change to the effective composition of the media used here may be quantitatively represented by the reduction of the zeta potential of the respective particles on going from water to the media. Figure 9 shows a correlation of the observed toxic response in the Daphnia magna system after 24 $\mathrm{h}$ with the change in the zeta potential of the polymer nanoparticles in the Daphnia medium. Thus the interaction of the particles with the medium can be correlated with the 
toxic response suggesting a secondary toxic mechanism, similar to that observed in mammalian cells exposed to single walled carbon nanotube samples. Although the media for the test species employed here is very different in nature to that used for mammalian cytotoxicity, in that it is made up of salts to modify the aqueous environment rather than essential nutrients, the interaction with the medium components implied here could result in changes in the ionic strength of the media and similarly contribute to the toxic response observed. This correlation of response to reduction of zeta potential does not simply correlate to all endpoints for a given particle composition however, and the correlation with the remnant particle zeta potential demonstrated in Figures 8 implies an intrinsic primary toxic response which is dependent on nanoparticle composition. Further studies of particle uptake by the different species are therefore merited to further understand the mechanisms underlying the toxic response. Additionally, parallel studies on the test species in media systematically depleted of individual salt components may shed additional light on the toxicity mechanism.

\section{Conclusions}

PNIPAM and NIPAM/BAM nanoparticles are well known thermoresponsive particles and to the best of our knowledge there is no ecotoxicity data of NIPAM/BAM nanoparticles available to date. The most sensitive ecotoxicological assay for PNIPAM and NIPAM/BAM 85:15 nanoparticles was the immobilisation of Daphnia magna (48 hour $\mathrm{EC}_{50}$ ) and for NIPAM/BAM 65:35 and NIPAM/BAM 50:50 nanoparticles was the Microtox ${ }^{\circledR}$ assay (Vibrio fischeri, 5 minutes $\mathrm{EC}_{50}$ ). The least sensitive bioassay was Pseudokirchneriella subcapitata $\left(72 \mathrm{~h} \mathrm{EC}_{50}\right)$ for the four nanomaterials tested. An important conclusion from the study therefore is that the sensitivity of each assay is dependent on the physico-chemical 
characteristics of the particle, emphasising the importance of a multi-trophic approach. As the ratio of BAM increases in the copolymer nanoparticle the toxicity was increased in all the test species, despite the fact that the particles with the highest ratio of BAM were highly aggregated. The toxicity trend for different nanoparticles was NIPAM $<$ NIPAM/BAM 85:15 < NIPAM/BAM 65:35< NIPAM/BAM 50:50, which suggests that there is a significant effect due to particle hydrophobicity and the surface free energy (Lynch et al., 2005). This is confirmed by the correlation of the toxic response with the observed zeta potential of the particles in the medium. The correlation of the toxic response in Daphnia magna with the reduction in zeta potential points towards a contribution of secondary effects due to modification of the medium. No dependence of the toxic response on the particle size was observed however. Nevertheless the study gives a clear dependence of the toxic response on the particle composition pointing towards structure-activity relationships.

The observed effects and interpretation of their consequences for nanoparticle fate and behaviour in the environment will be probed in further detail via the utilisation of bulk-fluorescently labelled particles of identical composition, allowing visualisation of the interaction between the particles and test species.

\section{Acknowledgements}

This work was conducted under the framework of the INSPIRE programme, funded by the Irish Government's Programme for Research in Third Level Institutions, Cycle 4, National Development Plan 2007-2013. Additional funding from EPA (TT, 2006PhD-RCA-19) and EU FP6 STREP project NanoInteract (IL) is acknowledged. We sincerely thank the Shannon Aquatic Toxicology Laboratory (SATL) especially Mr. 
Robert Hernan and Ms. Kathleen O’ Rourke for providing Daphnia magna start up cultures. 


\section{List of Figure Legends}

Figure 1 (a) and (b). Particle size measurement of different nanoparticles in Microtox diluent (MD) as a function of increasing temperature. (- $\mathbf{\Delta}-$ PNIPAM; $-\Delta-$ $\mathrm{P}(\mathrm{NIPAM} / \mathrm{BAM})$ 85:15; — $\mathrm{P}(\mathrm{NIPAM} / \mathrm{BAM})$ 65:35; and ——- P(NIPAM/BAM) 50:50 nanoparticles. Data is presented as the mean $\pm \mathrm{SD}(\mathrm{N}=6)$.

Figure 2. Zeta potential of PNIPAM and P(NIPAM/BAM) copolymer particles in different media. ( $\square$ MQ; $(\square)$ AM; $(\square)$ MD; $(\square)$ DM. Data is presented as the mean $\pm \mathrm{SD}(\mathrm{N}=6)$.

Figure 3. Effect of NIPAM and NIPAM/BAM nanoparticles on algal growth inhibition. ( $\square$ ) NIPAM; ( $\square$ ) NIPAM/BAM 85:15; ( $\square$ NIPAM/BAM 65:35; ( $\square$ ) NIPAM/BAM 50:50. Data is presented as the mean $\pm \mathrm{SD}(\mathrm{N}=3)$. *Denotes significant difference from control $(P \leq 0.05)$.

Figure 4. Effect of PNIPAM (a); P(NIPAM/BAM) 85:15 (b); P(NIPAM/BAM) 65:35 (c); and P(NIPAM/BAM) 50:50 (d) particles on immobilisation of Daphnia magna after ( $\square$ ) 24 hour and ( $\square$ ) 48 hours. Data is presented as the mean \pm SD (N=3). *Denotes significant difference from control $(P \leq 0.05)$.

Figure 5. Effect of PNIPAM ( $\square$ ) and P(NIPAM/BAM) 85:15 ( $\square$ ) (a); P(NIPAM/BAM) 65:35 (b); and P(NIPAM/BAM) 50:50 (c) particles on lethality of 
Thamnocephalus platyurus. Data is presented as the mean $\pm \mathrm{SD}(\mathrm{N}=3)$. *Denotes significant difference from control $(P \leq 0.05)$.

Figure 6. Relationship between 24 hour $(\square)$ and 48 hour $(\square) \mathrm{EC}_{50}$ for immobilisation of Daphnia magna following exposure to PNIPAM and different NIPAM/BAM copolymer particles.

Figure 7. Effect of PNIPAM and different NIPAM/BAM copolymer nanoparticles on $24 \mathrm{~h} \mathrm{LC}_{50}$ in Thamnocephalus platyurus.

Figure 8. Effect of zeta potential of different copolymer nanoparticles on immobilisation of Daphnia magna based on the $(\square) 24$ hour; ( $\square$ ) and 48 hour EC $_{50}$ results.

Figure 9. Correlation between change in zeta potential and $\mathrm{EC}_{50}$ in immobilisation of Daphnia magna with different NIPAM and NIPAM/BAM copolymer. 


\section{List of Table legends}

Table 1. Particle size of PNIPAM and NIPAM/BAM copolymer nanoparticles in different test media and temperature.

Table 2. Ecotoxicity data for poly- $N$-isopropylacrylamide P(NIPAM) nanoparticles on selected test species and endpoints.

Table 3. Ecotoxicity data for $N$-isopropylacrylamide-co- $N$-tert-butylacrylamide (NIPAM/BAM 85:15) copolymer nanoparticles on selected test species and endpoints.

Table 4. Ecotoxicity data for $N$-isopropylacrylamide-co- $N$-tert-butylacrylamide (NIPAM/BAM 65:35) copolymer nanoparticles on selected test species and endpoints.

Table 5. Ecotoxicity data for $N$-isopropylacrylamide-co- $N$-tert-butylacrylamide (NIPAM/BAM 50:50) copolymer nanoparticles on selected test species and endpoints 


\section{References}

Allen, L. T., Fox, E.J., Blute, I., Kelly, Z.D., Rochev, Y., Keenan, A.K., Dawson, K.A., Gallagher, W.M., 2003. Interactions of soft condensed materials with living cells: phenotype/transcriptome correlations for the hydrophobic effect. Proc. Natl. Acad. Sci. USA.100, 6331-6336.

Azur Environmental (1998). Microtox ${ }^{\circledR}$ acute toxicity basic test procedures, Report, Carlsbad, CA. pp 1-13.

Blasi, P., Giovagnoli, S., Schoubben, A., Ricci, M., Rossi, C., 2007. Solid lipid nanoparticles for targeted brain drug delivery. Adv. Drug Del. Rev. 59, 454-477.

Baun, A., Sorensen, S.N., Rasmussen, R.F., Hartmann, N.B., Koch, C.B., 2008. Toxicity and bioaccumulation of xenobiotic organic compounds in the presence of aqueous suspensions of aggregates of nano- $\mathrm{C}_{60}$. Aquat. Toxicol. 86, 379-387.

BS EN ISO 6341 (1996). Water Quality Determination of the Inhibition of the Mobility of Daphnia magna Strauss (Cladocera, Crustacea) Acute Toxicity Test. British Standards Institution, London. 
Cabaleiro-Lago, C., Quinlan-Pluck, F., Lynch, I., Lindman, S., Minogue, A.M., Thulin, E., Walsh, D.M., Dawson, K.A., Linse, S. 2008. Inhibition of amyloid $\beta$ protein fibrillation by polymeric nanoparticles. JACS, in press.

Casey, A., Herzog, E., Lyng, F.M., Byrne, H.J., Chambers, G., Davoren, M., 2008. Single walled carbon nanotubes induce indirect cytotoxicity by medium depletion in A549 lung cells. Toxicol. Lett.179, 78-84.

Cedervall, T., Lynch, I., Foy, M., Berggård, T., Donnelly, S.C., Cagney, G., Linse, S., Dawson, K.A., 2007. Detailed identification of plasma proteins adsorbed on copolymer nanoparticles. Angew. Chem. Int. Ed. Engl. 46, 5754-5756.

Cheng, J., Flahaut, E., Cheng, S.H., 2007. Effect of carbon nanotubes on developing zebrafish (Danio rerio) embryos. Environmental Toxicology and Chemistry. 26, 708716.

Davoren, M., Fogarty, M., 2006. In vitro cytotoxicity assessment of the biocidal agents sodium o-phenylphenol, sodium o-benzyl-p-chlorophenol, and sodium ptertiary amylphenol using established fish cell lines. Toxicol. In Vitro 20, 1190-1201.

Davoren, M., Ní Shuílleabháin, S., Hartl, M.G.J., Sheehan, D., O’Brien, N.M., O’Halloran, J., Van Pelt, F.N.A.M., Mothersill, C., 2005. Assessing the potential of 
fish cell lines as tools for the cytotoxicity testing of estuarine sediment aqueous elutriates. Toxicol. In Vitro 19, 421-431.

Dobrovolskaia, M.A., McNeil, SC., 2007, Immunological properties of engineered nanomaterials. Nat. Nanotechnol. 2, 469-478.

Federici, G., Shaw, B.J., Handy, R.D., 2007. Toxicity of titanium dioxide nanoparticles to rainbow trout (Oncorhynchus mykiss): Gill injury, oxidative stress, and other physiological effects. Aquat. Toxicol. 84, 415-430.

Gagńe, F., Auclair, J., Turcotte, P., Fournier, M., Gagnon, C., Sauve, S., Blaise, C., 2008. Ecotoxicity of CdTe quanum dots to fresh water mussels: Impacts on immune system, oxidative stress and genotoxicity. Aquat. Toxicol. 86, 333-340.

Hang, J. Z., Zhang, Y. F., Shi, L. Y., Feng, X., 2007. Electrokinetic properties of barite nanoparticles suspensions in different electrolyte media. Journal of Materials Science. 42, 9611-9616.

Heinlaan, M., Ivask, A., Blinova, I., Dubourguier, H.C., Kahru, A., 2008. Toxicity of nanosized and bulk $\mathrm{ZnO}, \mathrm{CuO}$ and $\mathrm{TiO}_{2}$ to bacteria Vibrio fischeri and crustaceans Daphnia magna and Thamnocephalus platyurus. Chemosphere. 71, 1308-1316. 
Hsiue, G.H., Chang, R.W., Wang, C.H., Lee, S.H., 2003. Development of in situ thermosensitive drug vehicles for glaucoma therapy. Biomaterials. 24, 2423-2430.

Hsiue, G.H., Hsu, S.H., Yang, C.C., Lee, S.H., Yang, I.K., 2002. Preparation of control release ophthalmic drops, for glaucoma therapy using thermosensitive poly- $N$ isopropylacrylamide. Biomaterials. 23, 457-462.

Ito, F., Fujimori, H., Honnamia, H., Kawakamid, H., Kanamura, K., Makino, K., 2008. Effect of polyethylene glycol on preparation of rifampicin-loaded PLGA microspheres with membrane emulsification technique. Colloids and Surfaces B: Biointerfaces. 66: 65-70.

Kavanagh, C.A., Gorelova, T.A., Selezneva, I.I., Rochev, Y.A., Dawson, K.A., Gallagher, W.M., Gorelov, A.V., Keenan, A.K. 2005. Poly(N-isopropylacrylamide) copolymer films as vehicles for the sustained delivery of proteins to vascular endothelial cells. J. Biomed. Mater. Res. A. 72, 25-35.

Kim, J.Y., Cohen,C., Shuler, M.L., 2000. Use of amphiphilic polymer particles for in situ extraction of sorbed phenanthrene from a contaminated aquifer material. Environ. Sci. Technol. 34, 4133-4139. 
Kim, J.Y., Shim, S.B., Shim, J.K., 2003a. Effect of amphiphilic polyurethane nanoparticles on sorption-desorption of phenanthrene in aquifer material. J. Hazard. Mater. 98, 145-160.

Kim, J.Y., Shim, S.B., Shim, J.K., 2003b. Synthesis of amphiphilic polyurethane nanonetwork particles and their application for the soil-washing process. J. Appl. Polymer Sci. 87, 1666-1677.

Lin, D., Xing, B., 2007. Phytotoxicity of nanoparticles: Inhibition of seed germination and root growth. Environ. Pollut.150, 243-50.

Linse, S., Lago, C.C., Xue, W.F., Lynch, I., Lindman, S., Thulin, E., Radford, S.E., Dawson, K.A., 2007. Nucleation of protein fibrillation by nanoparticles. Proc. Natl. Acad. Sci. USA. 104, 8691-8696.

Lovern, S.B., Klaper, R., 2006. Daphnia magna mortality when exposed to titanium dioxide and fullerene $\left(\mathrm{C}_{60}\right)$ nanoparticles. Environmental Toxicology and Chemistry. $25,1132-1137$.

Lovern, S.B., Strickler J.R., Klaper, R., 2007. Behavioral and physiological changes in Daphnia magna when exposed to nanoparticle suspensions (titanium dioxide, nanoC60, and C60HxC70Hx). Environ. Sci. Technol. 41, 4465-7. 
Lynch, I., Blute, I.A., Zhmud, B., MacArtain, P., Tosetto, M., Allen, L.T., Byrne, H.J., Farrell, G.F., Keenan, A.K., Gallagher, W.M., Dawson, K.A. 2005. Correlation of the Adhesive Properties of Cells to $N$-Isopropylacrylamide/ $N$-tert-Butylacrylamide Copolymer Surfaces with Changes in Surface Structure Using Contact Angle Measurements, Molecular Simulations, and Raman Spectroscopy. Chem. Mater. 17, $3889-3898$.

Meng, H., Chen, Z., Xing, G., Yuan, H., Chen, C., Zhao, F., Zhang, C., Zhao, Y., 2007.Ultrahigh reactivity provokes nanotoxicity: Explanation of oral toxicity of nano-copper particles. Toxicology Letters, 175, 102-110

Mortimer, M., Kasemets, K., Heinlaan, M., Kurvet, I., Kahru, A., 2008. High throughput kinetic Vibrio fischeri bioluminescence inhibition assay for study of toxic effects of nanopartcles. Toxicol. In Vitro, 22, 1412-1417.

Naha, P.C., Kanchan,V., Manna, P.K., Panda, A.K., 2008a. Improved bioavailability of orally delivered insulin using Eudragit L 30D coated PLGA microparticle. J. Microencapsul. 25, 248-256.

Naha, P.C., Kanchan, V., Panda, A.K., 2008b. Evaluation of parenteral depot insulin formulation using PLGA and PLA microparticles. J. Biomater. Appl. (In press) . 
Nowack, B., Bucheli, T.D., 2007. Occurence, behavior and effects of nanoparticles in the enironment. Environmental Pollution. 150, 5-22.

Nyholm, N. 1990. Expression of results from growth inhibition toxicity tests with algae. Arch. Environ. Contam. Toxicol. 19, 518-522.

Oberdörster, G., Oberdörster, E., Oberdörster, J., 2005. Nanotoxicology: an emerging discipline evolving from studies of ultra fine particles. Environ. Health Perspect. 113, 823-839.

OECD, 2002. Guideline for testing of chemicals. In: Freshwater Alga and Cyanobacteria, Growth Inhibition Test, Method 201, OECD.

Papageorgiou, I., Brown, C., Schins, R., Singh, S., Newson, R., Davis, S., Fisher, J., Ingham E., Case C.P. 2007. The effect of nano- and micron-sized particles of cobaltchromium alloy on human fibroblasts in vitro. Biomaterials 28, 2946-2958.

Poland, C.A., Duffin, R., Kinloch, I., Maynard, A., Wallace, W.A.H., Seaton, A., Stone, V., Brown, S., MacNee, W., Donaldson, K., 2008. Carbon nanotubes introduced into the abdominal cavity of mice show asbestos like pathogenicity in a pilot study. Nat. Nanotechnol. 3, 423-428. 
Silva, C.M., Ribeiro, A.J., Ferreira, D., Veiga, F., 2006. Insulin encapsulation in reinforced alginate microparticles prepared by internal gelation. Eur J Pharm Sci 29, $148-159$.

Singh,S., Shi, T., Duffin, R Albrecht, C., van Berlo, D., Höhr, D., Fubini, B., Martra, G., Fenoglio, I., Borm, P.J.A., Schins, R.P.F. 2007. Endocytosis, oxidative stress and IL-8 expression in human lung epithelial cells upon treatment with fine and ultrafine $\mathrm{TiO}_{2}$ : Role of the specific surface area and of surface methylation of the particles. Toxicol Appl Pharmacol. 222, 141-151

Smith, C.J., Shaw, B.J., Handy, R.D., 2007. Toxicity of single walled carbon nanotubes to rainbow trout, (Oncorhynchus mykiss): respiratory toxicity, organ pathologies, and other physiological effects. Aquat. Toxicol. 82, 94-109.

Storrie, H., Mooney, D. J., 2006. Sustained delivery of plasmid DNA from polymeric scaffolds for tissue engineering. Adv. Drug. Del. Rev. 58, 500-514.

Sun, Y., Wang, J.C., Zhang, X., Zhang. Z.J., Zheng, Y., Chen, D., Zhang, Q., 2008. Synchronic release of two hormonal contraceptives for about one month from the PLGA microspheres: In vitro and in vivo studies. J. Control Rel. 129: 192-199. 
Thamnotoxkit, FTM., 1995. Crustacean toxicity screening test for freshwater. Standard Operating Procedure, Creasal, Deinze, Belgium.

Xu, Y.H., Zhao, D.Y., 2005. Removal of copper from contaminated soil by use of poly(amidoamine) dendrimers. Environ. Sci. Technol. 39, 2369-2375.

Xu, Y.H., Zhao, D.Y., 2006. Removal of lead from contaminated soils using poly (amidoamine) dendrimers. Ind. Eng. Chem. Res. 45, $1758 \mathrm{e} 1765$.

Xu, F.J., Kang, E.T., Neoh, K.G., 2006. pH and temperature responsive hydrogel from crosslinked triblock copolymers prepared via consecutive atom transfer radical polymerization. Biomaterials. 27, 2787-2797.

Xu, F.Z., Zhong, S.P., Yung, L.Y.L., Kang, E.T., Neoh, K.G., 2004. Surface-active and stimuli-response polymer-Si(100) hybrid from surface-initiated atom transfer radical polymerization for control of cell adhesion. Biomacromolecules. 5, 23922403.

Zhang, X.Z., Yang, Y.Y., Chung, T.S., Ma, K.X., 2001. Preparation and Characterization of Fast Response Macroporous Poly( $N$-isopropylacrylamide) Hydrogels. Langmuir. 17, 6094-6099. 
Zhang, X.Z., Lewis, P.J., Chu, C.C., 2005. Fabrication and characterization of a smart drug delivery system: microsphere in hydrogel. Biomaterials. 26, 3299-3309.

Zhu, Y., Zhao, Q., Li, Y., Cai, X., Li,W., 2006. The interaction and toxicity of multiwalled carbon nanotubes with Stylonychia mytilus. J. Nanosci. Nanotechnol. 6, 13571364. 
Figure 1a.

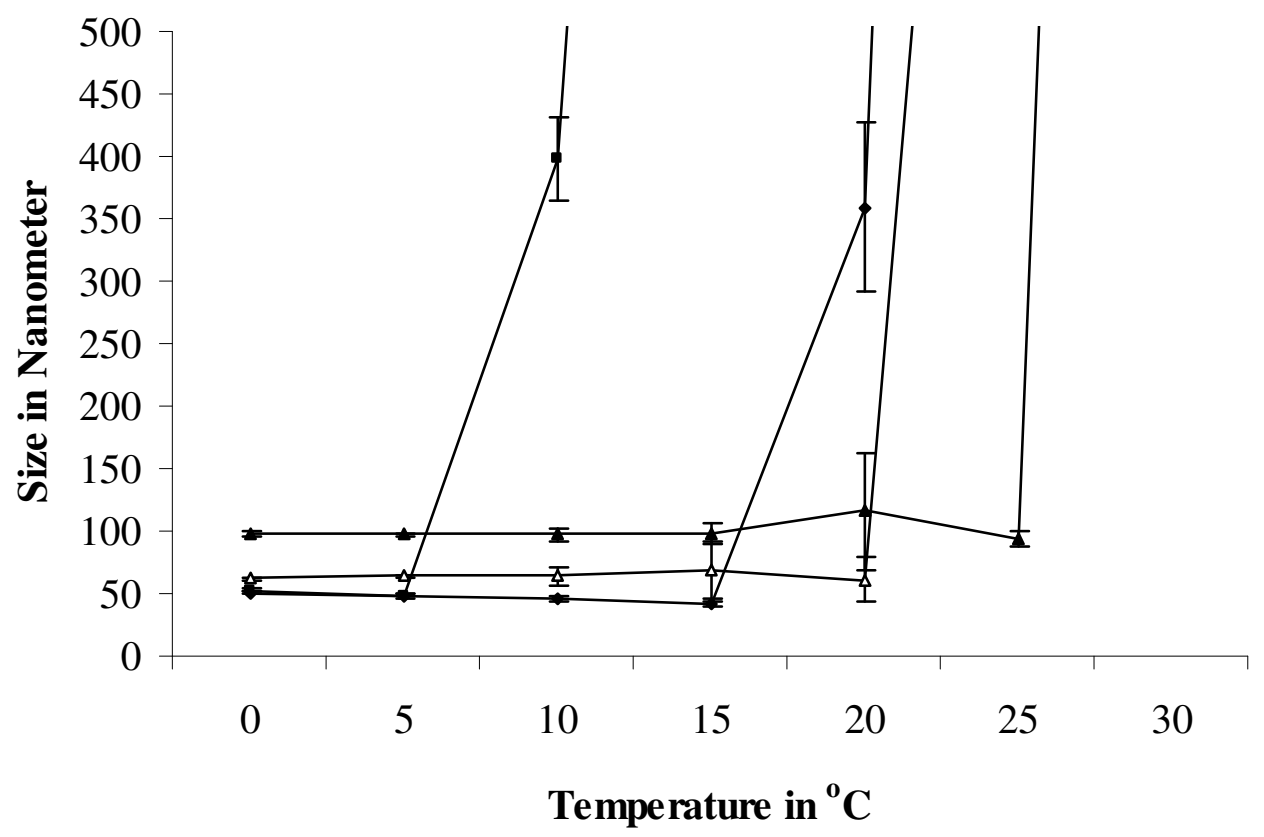

Figure 1b

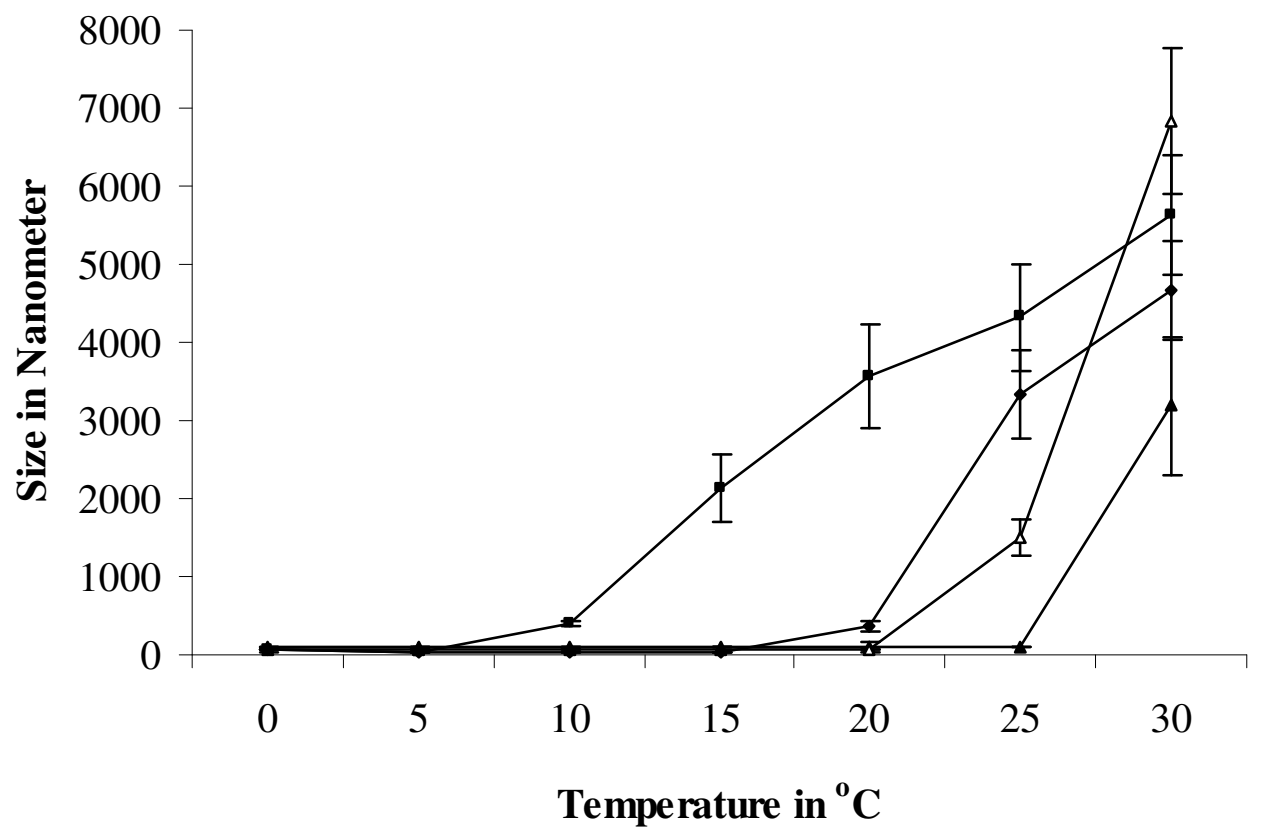


Figure 2.

Different NIPAM and NIPAM/BAM nanoparticles

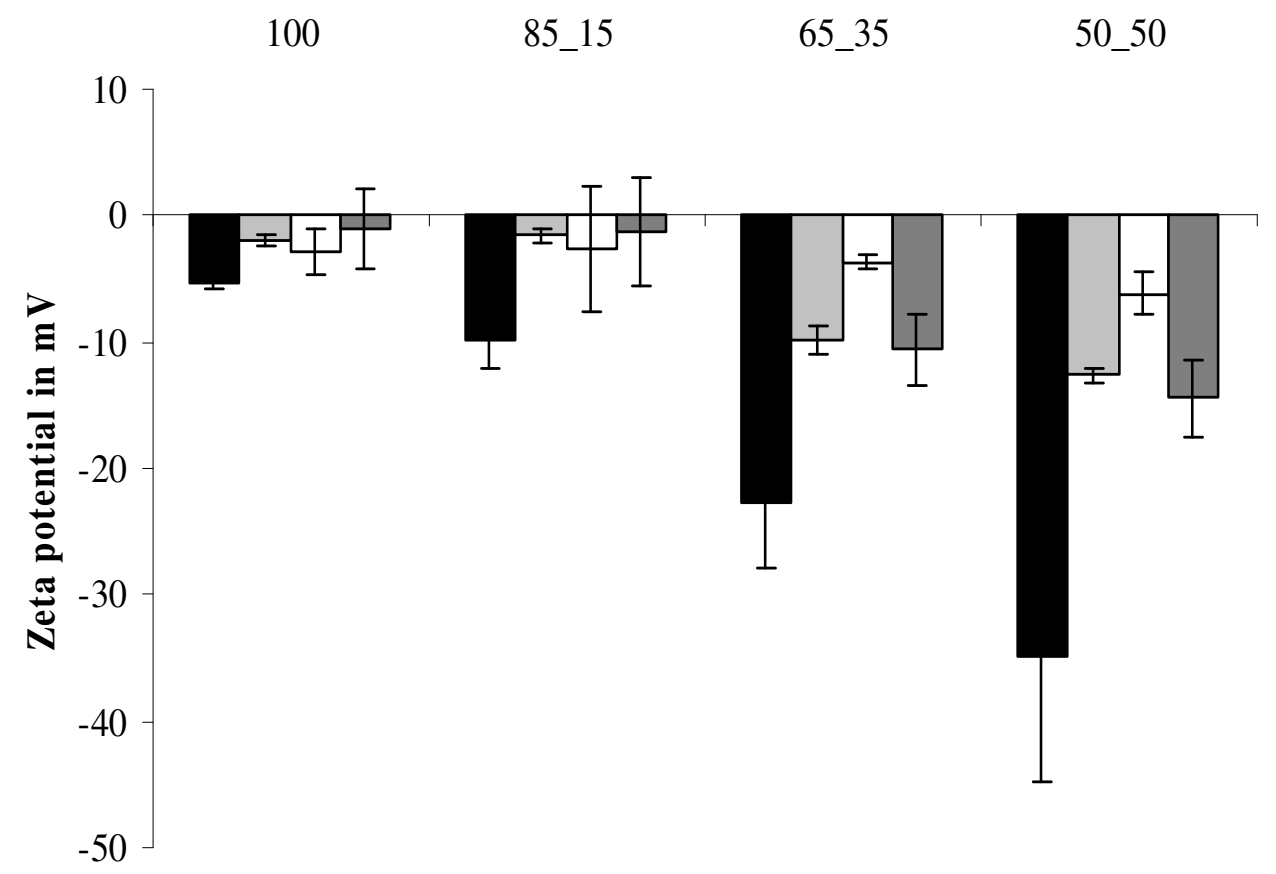


Figure 3.

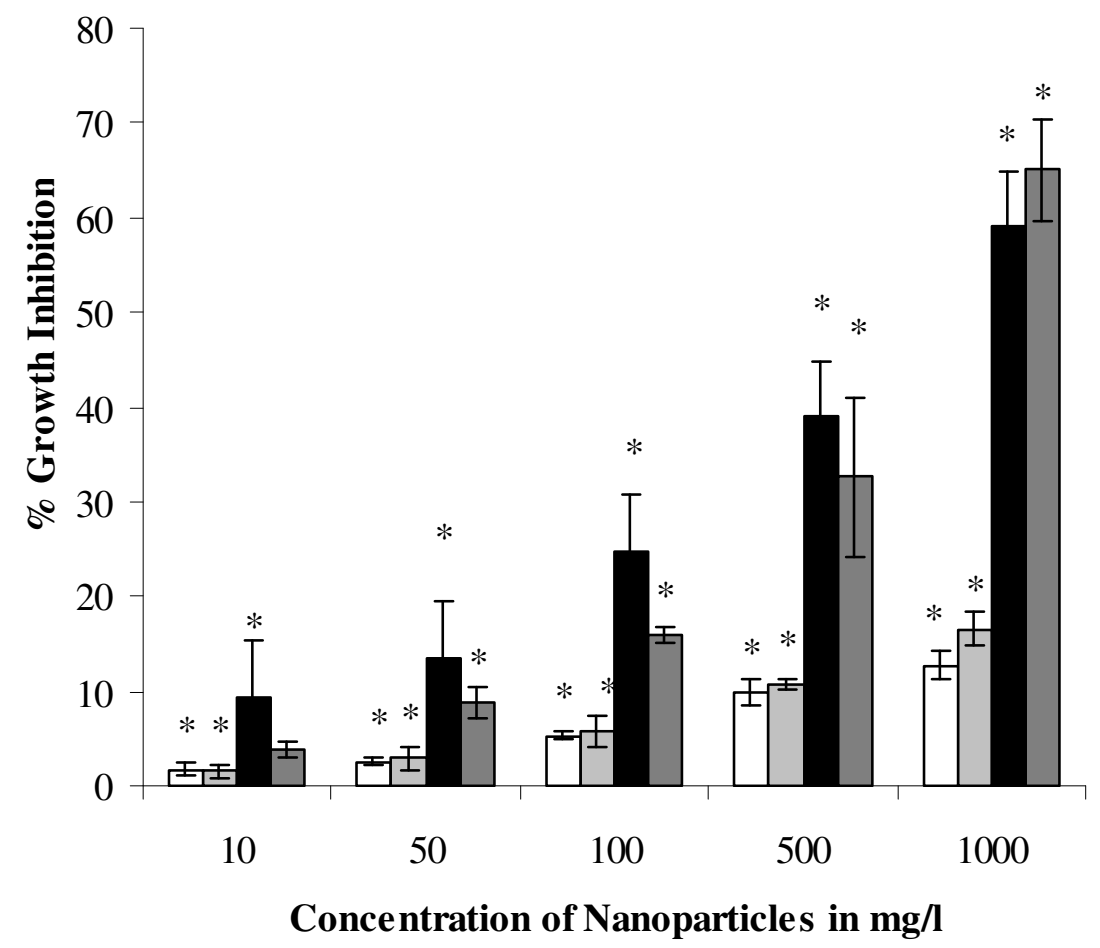


Figure 4a

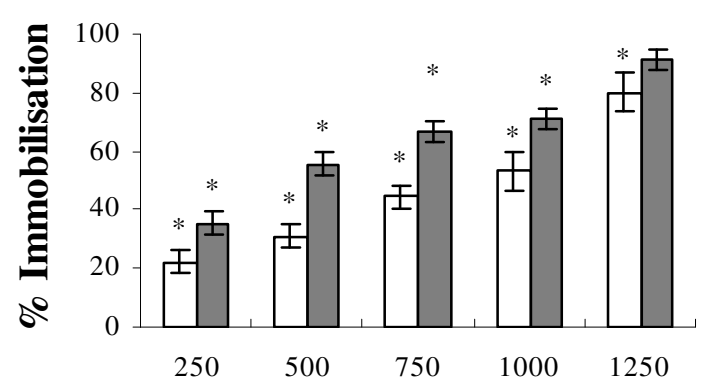

Figure $4 b$

Concentration of Nanoparticles in mg/l

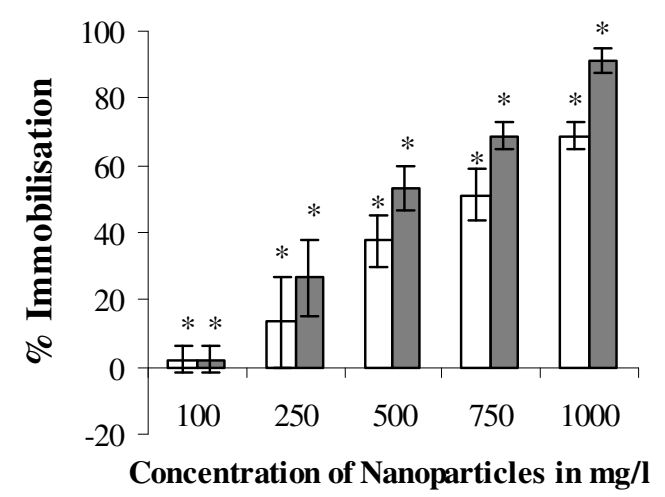

Figure 4c

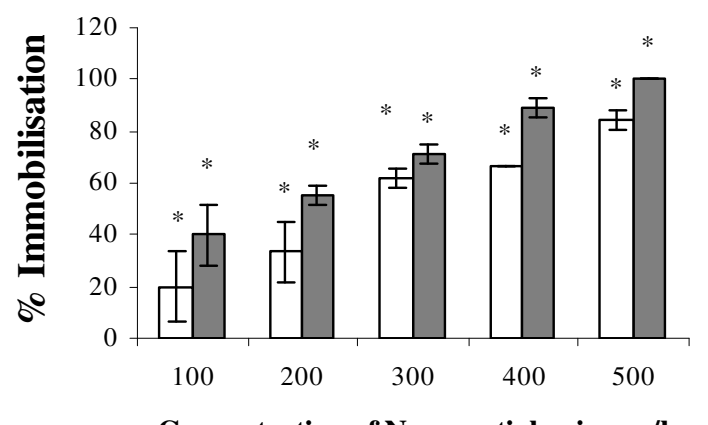

Figure 4d

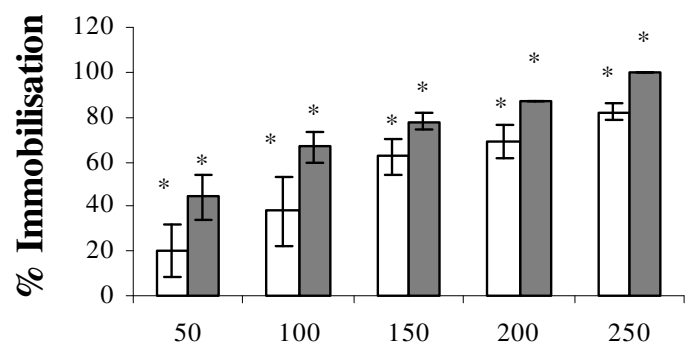

Concentration of Nanoparticles in mg/l 
Figure 5a.

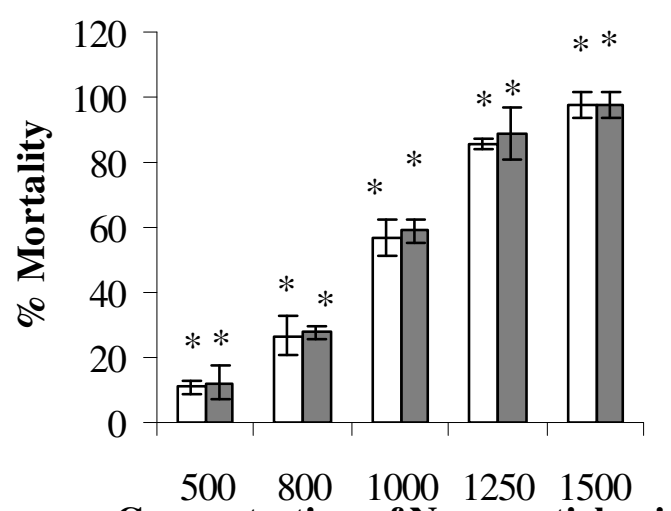

Concentration of Nanoparticles in $\mathrm{mg} / \mathrm{l}$

Figure 5b.

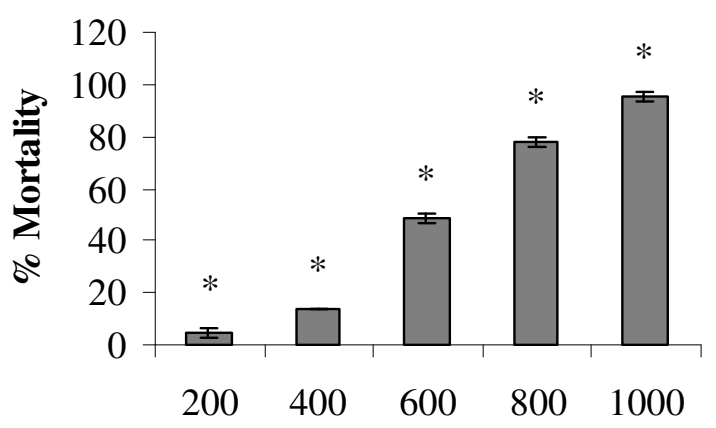

Concentration of Nanoparticles in $\mathrm{mg} / \mathrm{l}$

Figure 5c.

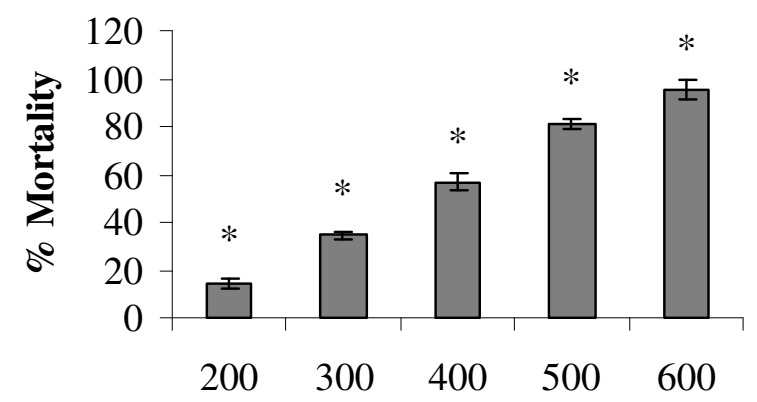

Concentration of Nanoparticles in mg/l 
Figure 6.

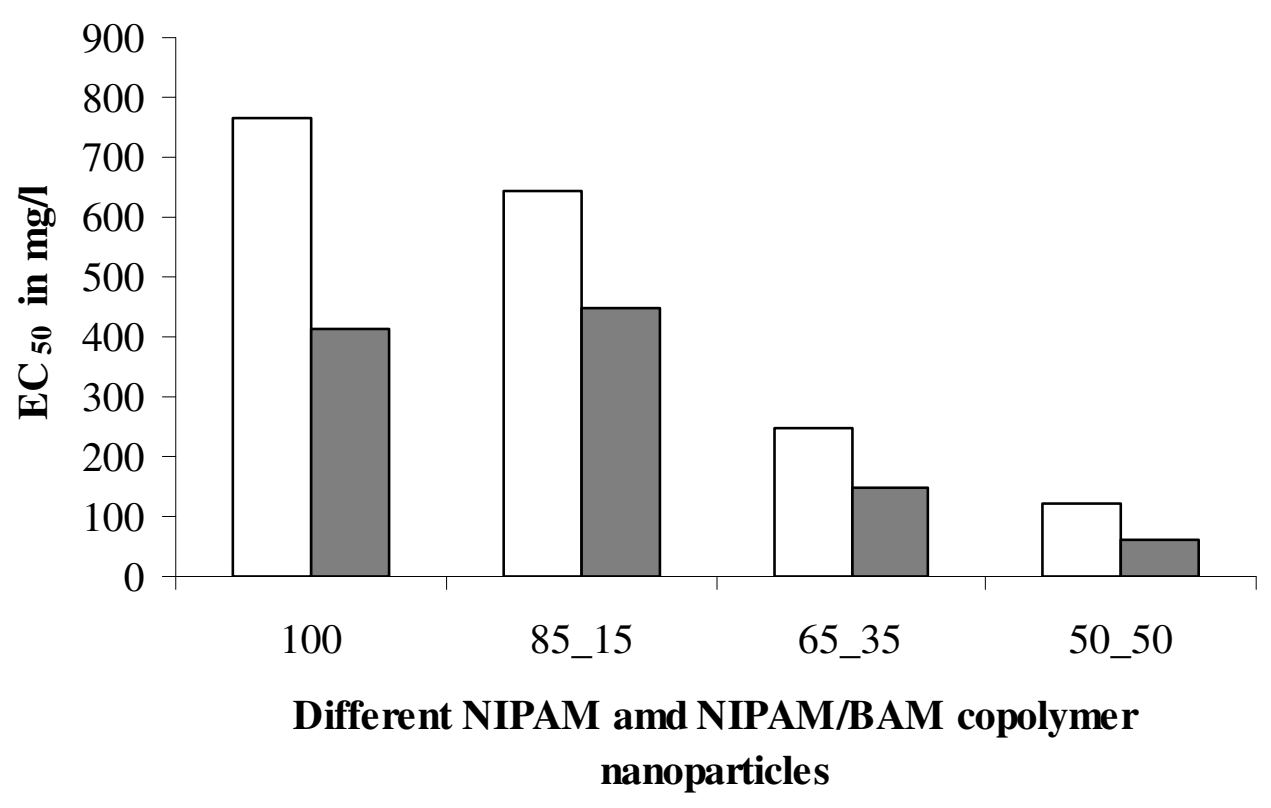


Figure 7

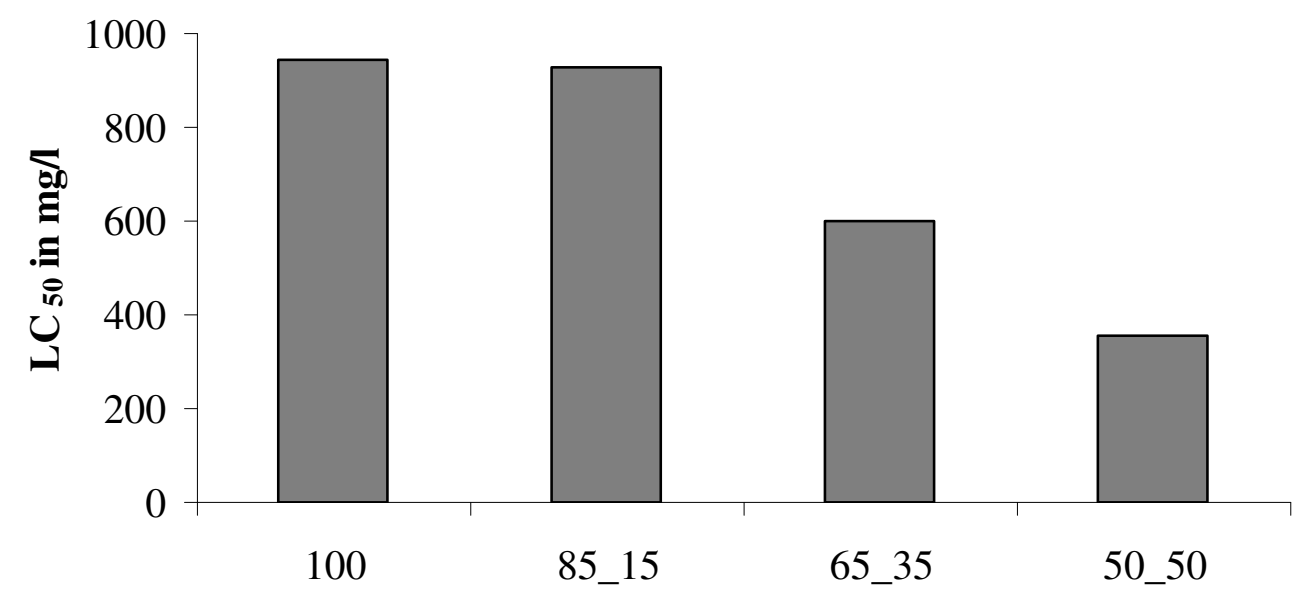

Different NIPAM/BAM copolymer nanoparticles 
Figure 8.

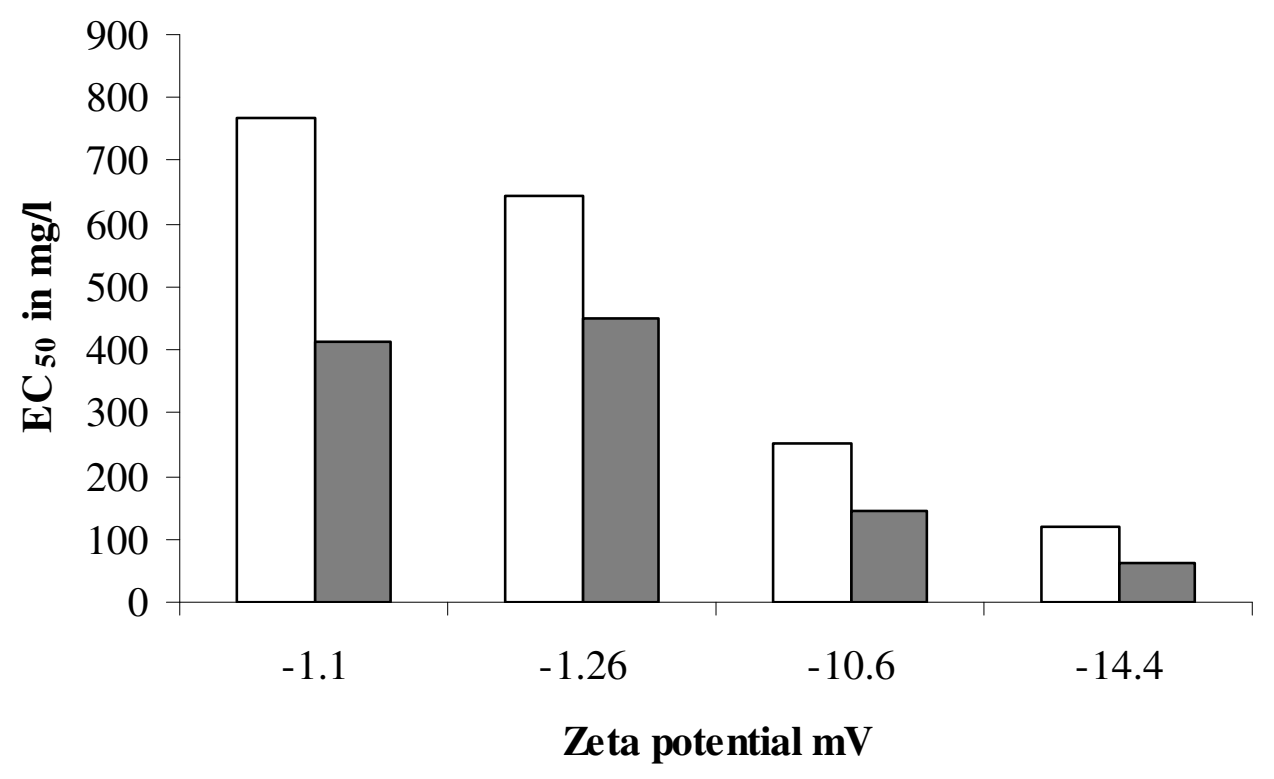


Figure 9.

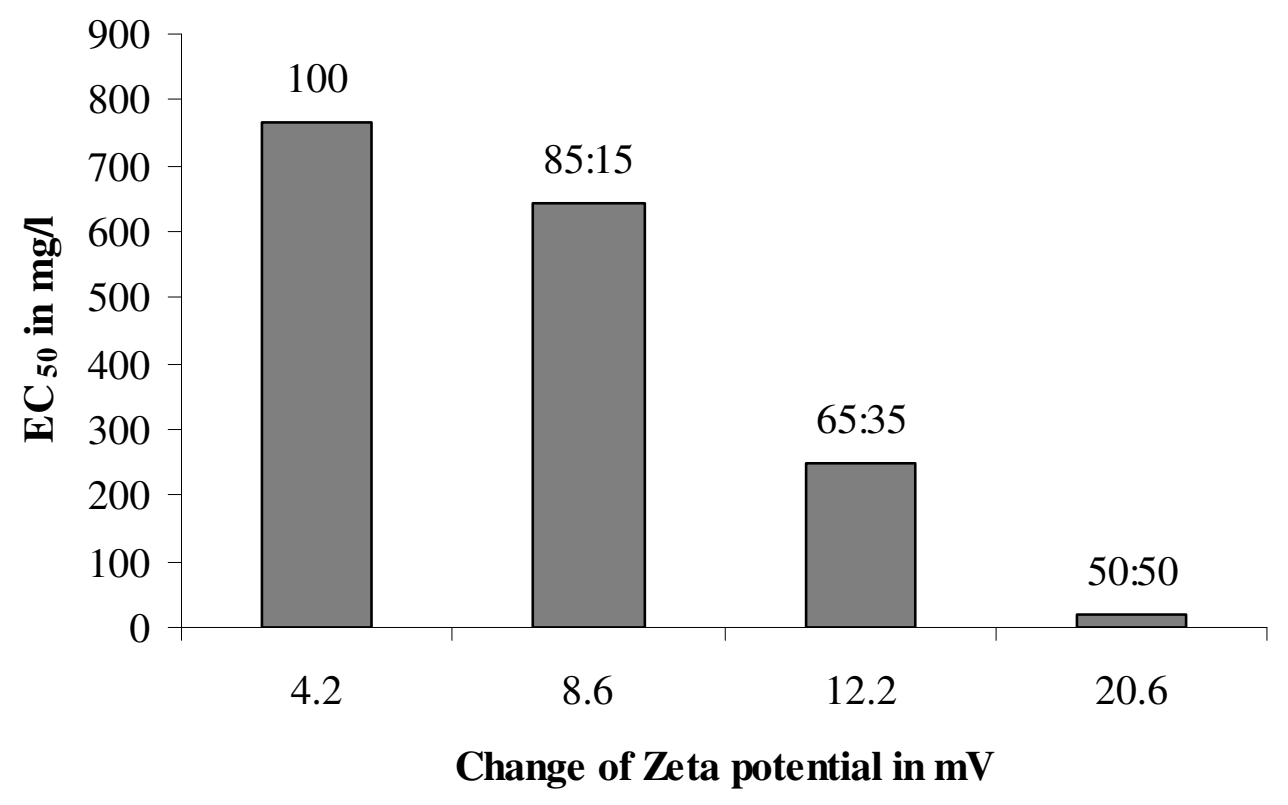


Table 1

\begin{tabular}{|c|c|c|c|c|c|}
\hline Test Medium & $\begin{array}{c}\text { Test } \\
\text { Temperature } \\
{ }^{\circ} \mathrm{C}\end{array}$ & NIPAM & $\begin{array}{c}\text { NIPAM/BAM } \\
85: 15\end{array}$ & $\begin{array}{c}\text { NIPAM/BAM } \\
65: 35\end{array}$ & $\begin{array}{c}\text { NIPAM/BAM } \\
50: 50\end{array}$ \\
\hline $\begin{array}{c}\text { Microtox } \\
\text { Diluent }\end{array}$ & 15 & $98 \mathrm{~nm}$ & $69 \mathrm{~nm}$ & $42 \mathrm{~nm}$ & $2131 \mathrm{~nm}$ \\
\hline $\begin{array}{c}\text { Algal Medium } \\
15\end{array}$ & 20 & $105 \mathrm{~nm}$ & $60 \mathrm{~nm}$ & $61 \mathrm{~nm}$ & $5765 \mathrm{~nm}$ \\
\hline $\begin{array}{c}\text { Daphnia } \\
\text { medium }\end{array}$ & 20 & $102 \mathrm{~nm}$ & $58 \mathrm{~nm}$ & $200 \mathrm{~nm}$ & $2789 \mathrm{~nm}$ \\
\hline
\end{tabular}


Table 2.

\begin{tabular}{|c|c|c|c|c|c|c|}
\hline $\begin{array}{l}\text { Test } \\
\text { Species }\end{array}$ & $\begin{array}{l}\text { End Point and } \\
\text { Concentration } \\
\text { Range tested } \\
\left(\mathrm{mg} \mathrm{l}^{-1}\right)\end{array}$ & $\begin{array}{l}\mathrm{EC}_{10} / \mathrm{LC}_{10} \\
\left(\mathrm{mg} \mathrm{l}^{-1}\right)\end{array}$ & $\begin{array}{l}\mathrm{EC}_{50} / \mathrm{LC}_{50} \\
\left(\mathrm{mg} \mathrm{l}^{-1}\right)\end{array}$ & $\begin{array}{l}\text { Maximum } \\
\text { Toxicity } \\
(\%)\end{array}$ & $\begin{array}{l}\mathrm{NOEC} \\
\left(\mathrm{mg} \mathrm{l}^{-1}\right)^{\mathrm{a}}\end{array}$ & $\begin{array}{l}\text { LOEC } \\
\left(\mathrm{mg} \mathrm{l}^{-1}\right)^{b}\end{array}$ \\
\hline V. fischeri & $\begin{array}{l}5 \mathrm{~min} \\
\text { inhibition } \\
(3.5-900)\end{array}$ & - & $>900$ & 21.5 & - & - \\
\hline $\begin{array}{l}P . \\
\text { subcapitata }\end{array}$ & $\begin{array}{l}72 \mathrm{~h} \text { inhibition } \\
(10-1000)\end{array}$ & 547.1 & $>1000$ & 12.75 & $<10$ & 10 \\
\hline D. magna & $\begin{array}{l}24 \mathrm{~h} \\
\text { immobilisation } \\
(250-1250)\end{array}$ & 190.1 & 766.4 & 80 & $<250$ & 250 \\
\hline D. magna & $\begin{array}{l}48 \mathrm{~h} \\
\text { immobilisation } \\
(250-1250)\end{array}$ & 82.5 & 413.6 & 91 & $<250$ & 250 \\
\hline $\begin{array}{l}T . \\
\text { platyurus }\end{array}$ & $\begin{array}{l}24 \text { h lethality } \\
(500-1500)\end{array}$ & 654.5 & 943.5 & 97.7 & $<500$ & 500 \\
\hline
\end{tabular}


Table 3.

\begin{tabular}{|c|c|c|c|c|c|c|}
\hline $\begin{array}{l}\text { Test } \\
\text { Species }\end{array}$ & $\begin{array}{l}\text { End Point and } \\
\text { Concentration } \\
\text { Range tested } \\
\left(\mathrm{mg} \mathrm{l}^{-1}\right)\end{array}$ & $\begin{array}{l}\mathrm{EC}_{10} / \mathrm{LC}_{10} \\
\left(\mathrm{mg} \mathrm{l}^{-1}\right)\end{array}$ & $\begin{array}{l}\mathrm{EC}_{50} / \mathrm{LC}_{50} \\
\left(\mathrm{mg} \mathrm{l}^{-1}\right)\end{array}$ & $\begin{array}{l}\text { Maximum } \\
\text { Toxicity (\%) }\end{array}$ & $\begin{array}{l}\text { NOEC } \\
\left(\mathrm{mg} \mathrm{l}^{-1}\right)^{\mathrm{a}}\end{array}$ & $\begin{array}{l}\text { LOEC } \\
\left(\mathrm{mg} \mathrm{l}^{-1}\right)^{\mathrm{b}}\end{array}$ \\
\hline V. fischeri & $\begin{array}{l}5 \text { min } \\
\text { inhibition } \\
(3.5-900)\end{array}$ & 119.6 & $>900$ & 44.3 & $<900$ & 900 \\
\hline $\begin{array}{l}P . \\
\text { subcapitata }\end{array}$ & $\begin{array}{l}72 \mathrm{~h} \text { inhibition } \\
(10-1000)\end{array}$ & - & $>1000$ & 16.6 & $<10$ & 10 \\
\hline D. magna & $\begin{array}{l}24 \mathrm{~h} \\
\text { immobilisation } \\
(100-1000)\end{array}$ & 208.7 & 643.4 & 68.9 & 250 & 500 \\
\hline D. magna & $\begin{array}{l}48 \mathrm{~h} \\
\text { immobilisation } \\
(100-1000)\end{array}$ & 153.9 & 449.6 & 91.1 & 100 & 250 \\
\hline $\begin{array}{l}\text { T. } \\
\text { platyurus }\end{array}$ & $\begin{array}{l}24 \text { h lethality } \\
(500-1500)\end{array}$ & 651.8 & 929.3 & 97.7 & $<500$ & 500 \\
\hline
\end{tabular}


Table 4.

\begin{tabular}{|c|c|c|c|c|c|c|}
\hline Test Species & $\begin{array}{l}\text { End Point and } \\
\text { Concentration } \\
\text { Range tested } \\
\left(\mathrm{mg} \mathrm{l}^{-1}\right)\end{array}$ & $\begin{array}{l}\mathrm{EC}_{10} / \mathrm{LC}_{10} \\
\left(\mathrm{mg} \mathrm{l}^{-1}\right)\end{array}$ & $\begin{array}{l}\mathrm{EC}_{50} / \mathrm{LC}_{50} \\
\left(\mathrm{mg} \mathrm{l}^{-1}\right)\end{array}$ & $\begin{array}{l}\text { Maximum } \\
\text { Toxicity } \\
(\%)\end{array}$ & $\begin{array}{l}\text { NOEC } \\
\left(\mathrm{mg} \mathrm{l}^{-1}\right)^{\mathrm{a}}\end{array}$ & $\begin{array}{l}\text { LOEC } \\
\left(\mathrm{mg} \mathrm{l}^{-1}\right)^{b}\end{array}$ \\
\hline V. fischeri & $\begin{array}{l}5 \text { min inhibition } \\
(3.5-900)\end{array}$ & - & 40.5 & 62 & $<14.06$ & 14.06 \\
\hline $\begin{array}{l}P . \\
\text { subcapitata }\end{array}$ & $\begin{array}{l}72 \mathrm{~h} \text { inhibition } \\
(10-1000)\end{array}$ & 21.6 & 727.1 & 58.9 & $<10$ & 10 \\
\hline D. magna & $\begin{array}{l}24 \mathrm{~h} \\
\text { immobilisation } \\
(100-500)\end{array}$ & 80.26 & 250.2 & 84 & 100 & 200 \\
\hline D. magna & $\begin{array}{l}48 \mathrm{~h} \\
\text { immobilisation } \\
(100-500)\end{array}$ & 40.37 & 146.2 & 100 & $<100$ & 100 \\
\hline T. platyurus & $\begin{array}{l}24 \text { h lethality } \\
(200-1000)\end{array}$ & 380.6 & 602.8 & 95.5 & $<200$ & 200 \\
\hline
\end{tabular}


Table 5.

\begin{tabular}{|c|c|c|c|c|c|c|}
\hline $\begin{array}{l}\text { Test } \\
\text { Species }\end{array}$ & $\begin{array}{l}\text { End Point and } \\
\text { Concentration } \\
\text { Range tested } \\
\left(\mathrm{mg} \mathrm{l}^{-1}\right)\end{array}$ & $\begin{array}{l}\mathrm{EC}_{10} / \mathrm{LC}_{10} \\
\left(\mathrm{mg} \mathrm{l}^{-1}\right)\end{array}$ & $\begin{array}{l}\mathrm{EC}_{50} / \mathrm{LC}_{50} \\
\left(\mathrm{mg} \mathrm{l}^{-1}\right)\end{array}$ & $\begin{array}{l}\text { Maximum } \\
\text { Toxicity } \\
(\%)\end{array}$ & $\begin{array}{l}\text { NOEC } \\
\left(\mathrm{mg} \mathrm{l}^{-1}\right)^{\mathrm{a}}\end{array}$ & $\begin{array}{l}\text { LOEC } \\
\left(\mathrm{mg} \mathrm{l}^{-1}\right)^{b}\end{array}$ \\
\hline V. fischeri & $\begin{array}{l}5 \text { min } \\
\text { inhibition } \\
(3.5-900)\end{array}$ & - & 25.7 & 71.3 & $<28.3$ & 28.3 \\
\hline $\begin{array}{l}P . \\
\text { subcapitata }\end{array}$ & $\begin{array}{l}72 \mathrm{~h} \text { inhibition } \\
(10-1000)\end{array}$ & 78.5 & 706.7 & 65 & 10 & 50 \\
\hline D. magna & $\begin{array}{l}24 \mathrm{~h} \\
\text { immobilisation } \\
(50-250)\end{array}$ & 35.9 & 120.3 & 82.2 & 50 & 100 \\
\hline D. magna & $\begin{array}{l}48 \mathrm{~h} \\
\text { immobilisation } \\
(50-250)\end{array}$ & 15.7 & 60.59 & 100 & $<50$ & 50 \\
\hline $\begin{array}{l}T . \\
\text { platyurus }\end{array}$ & $\begin{array}{l}24 \text { h lethality } \\
(200-600)\end{array}$ & 202.8 & 353.1 & 95.5 & $<200$ & 200 \\
\hline
\end{tabular}

